\title{
The first records of Symphyla (Myriapoda) in Siberia, Russia
}

\section{Первые находки Symphyla (Myriapoda) в Сибири (Россия)}

\author{
Pavel S. Nefediev', Karin Voigtländer ${ }^{2}$, \\ Ulrich Burkhardt ${ }^{2}$, Peter Decker ${ }^{2}$ \\ П.С. Нефедьев ${ }^{1}$, К. Фойгтмэндер ${ }^{2}$, У. БуркхарАт ${ }^{2}$, П. Аекер ${ }^{2}$
}

\footnotetext{
${ }^{1}$ Altai State University, Lenina Avenue, 61, Barnaul 656049 Russia. E-mail: p.nefediev@mail.ru

${ }^{1}$ Алтайский государственный университет, проспект Ленина, 61, Барнаул 656049 Россия.

${ }^{2}$ Senckenberg Museum of Natural History, Department of Soil Zoology, PF 3001 54, 02806 Görlitz, Germany.
}

KEY WORDS: Symphyla, Symphylella vulgaris, Scutigerella causeyae, Hanseniella, faunistics, Siberia, Russia.

КЛЮЧЕВЫЕ СЛОВА: Симфилы, Symphylella vulgaris, Scutigerella causeyae, Hanseniella, фаунистика, Сибирь, Россия.

ABSTRACT. The first records on garden centipedes of the class Symphyla in the south of western Siberia, Russia concern at least three species: Symphylella cf. vulgaris (Hansen, 1903), Scutigerella causeyae Michelbacher, 1942, and Hanseniella sp. The latter genus is new to the fauna of Asian Russia, while the penultimate species is the first record in Russia.

PЕЗЮМЕ: Первые сведения по многоножкам класса Symphyla с юга Западной Сибири включают по меньшей мере три вида: Symphylella cf. vulgaris (Hansen, 1903), Scutigerella causeyae Michelbacher, 1942 и Hanseniella sp. Последний род является новым для фауны азиатской части России, а предпоследний вид - первая находка в России.

\section{Introduction}

The first review of garden centipedes of the class Symphyla in the USSR was by Scheller and Golovatch [1982]. According to these authors, six verified symphylan species inhabit the territory of the Russian Federation: Symphylella vulgaris from the Moscow Area and the Ussuri State Nature Reserve, Maritime Province, Russian Far East; S. isabellae (Grassi, 1886), from the environs of the city of Moscow; Scutigerella linsleyi Michelbacher, 1942, from the Nikita Botanical Garden, Republic of Crimea; S. immaculata (Newport, 1845), from hothouses and open grounds near St. Petersburg, Leningrad Area, as well as from the Krasnodar Province, near the city of Sochi, and from the Crimea; Hanseniella nivea (Scopoli, 1763), from the Krasnodar Province, near the city of Sochi; Scolopendrella notacantha Gervais, 1844, from the Krasnodar Province, near the city of Sochi, as well as from the Crimea and a hothouse of the Botanical Garden, St. Petersburg, Leningrad Area. Three latter species were mentioned as doubtful records.
More recent records of Symphyla from the city of Vladivostok, Russian Far East [Scheller, Mikhaljova, 2001], including S. vulgaris, S. immaculata and Scutigerella palmonii Michelbacher, 1942, have enlarged the list of symphylans in Russia to seven species. The latest records of a Scutigerella sp., from the city of Perm, European Russia [Farzalieva, 2008], are doubtful, because the author mentioned only 11 pairs of legs for her study specimens in the identification keys to the Myriapoda of the Urals.

\section{Material and methods}

Morphological characters of fifteen specimens of symphylans were studied using a Leica DM 1000 microscope. The main publications used for identification were Hansen [1903], Michelbacher [1942], Edwards [1959], Scheller [1978], Scheller and Adis [1996], Andersson et al. [2005], and Domínguez Camacho [2009]. All specimens are preserved in 70\% ethanol or mounted on slides in gum-chloral media. The material treated herein is mainly deposited in the collection of the Altai State University, Barnaul, Russia (ASU), partly also in the collection of the Senckenberg Museum of Natural History in Görlitz, Germany (SMNG), as indicated in the text.

\section{Taxonomic part}

Family SCOLOPENDRELLIDAE

Symphylella cf. vulgaris (Hansen, 1903)

MATERIAL EXAMINED. $2 O^{\top} \sigma^{\top}$ (ASU), Russia, southwestern Siberia, Tomsk Area, Tomsk City, Siberian Botanical Garden, hothouse, 10.XII.1999, leg. P.S. Nefediev.

DISTRIBUTION. S. vulgaris (Hansen, 1903) is very widespread in Europe, and is one of the most 
eurytopic species among the symphylans [Voigtländer et al., 2016]: Britain including the Shetlands, the Orkneys, the Hebrides, and also the Isle of Man, Ireland, mainland France and Corsica, Switzerland, Germany, Austria, Hungary, Czech Republic, Slovakia, Slovenia, Serbia including Voivodina, Kosovo, Montenegro, Bosnia and Herzegovina, Croatia, Albania, Bulgaria, Romania, Poland, mainland and insular Greece including Andikithira, Euboea, Samothrace, Thasos and archipelagos (the Ionian Islands and the Northern Sporades), mainland Italy together with Sicily and adjacent islands, mainland Spain including Alboran Island, mainland Denmark together with Bornholm Island, mainland Norway, Sweden including Gotland Island, Finland, as well as the central and southern parts of European Russia [Scheller, Stoev, 2006; Enghoff, Scheller, 2013].

REMARKS. The two specimens of Symphylella cf. vulgaris have been found in a hothouse of the Siberian Botanical Garden in the city of Tomsk, Tomsk Area. They agree with the description of Hansen [1903] by the following characters: 16 or 17 antennomeres; middle antennomeres with secondary whorl of setae placed at midlength; few circular spots on outer sides of all antennomeres; third and fourth tergites $\left(2^{\text {nd }}\right.$ and $3^{\text {rd }}$ scutum) longer than broad, with a distinct knob at tip of posterior tergite process; first leg-pair with a ring of short setae and one long seta in the middle; metatarsus of last pair of legs with two anterodorsal setae and pretarsus with three dorsal setae. The study specimens show preparation artifacts, and the following characters could be neither seen nor measured with certainty: ratio of tergite process length and distance between them; setation at outer margin of tergites $(3-4,4$ ?); orientation of tips of cerci (missing).

Some characters of the specimens studied here differ from the description of $S$. vulgaris (sensu Hansen, 1903), being more intermediate between the former species and closely related Symphylella species: inner margin of third tergite processes with three setae ( $S$. vulgaris: $2 ; S$. isabellae: 4); length to width ratio of cerci, 3.5 (S. vulgaris: 3 ; S. isabellae: 4-5); first tergite with transverse row of setae 3+4, 4+4 (see Edwards [1959]: S. vulgaris, $3+3$; S. isabellae, 4-6+4-6); ratio of process length to posterior margin between $4^{\text {th }}$ tergite processes, $1.3,1.05$ (S. vulgaris: 2 ; S. isabellae: $<1$ ).

Scheller and Golovatch [1982] described populations of $S$. vulgaris from the Ussuri State Nature Reserve, Far East of Russia, with the styli being semicircular instead of conical as in S. vulgaris (sensu Hansen, 1903), and tergite processes more elongated and slender. The two Siberian specimens of $S$. cf. vulgaris also show these two deviating characters, with processes of tergites showing the following length to width ratios: $2^{\text {nd }}$ tergite, 1.0 and $1.04 ; 3^{\text {rd }}$ tergite, 1.22 and 1.3. This indicates that those specimens are only similar to S. vulgaris. However, most of the features pretty well fit $S$. vulgaris, but some other characters are either different from those in $S$. vulgaris or intermediate towards $S$. isabellae. The taxonomic robustness and variability of these traits within Symphylella or generally in symphylans are not studied yet in due detail. Therefore, we decide to refer these specimens to S. cf. vulgaris.

\section{Symphylella sp.}

MATERIAL EXAMINED. 1 juv. (ASU), Russia, southwestern Siberia, Altai Province, Pervomaiskii District, Beryozki Railway Station, 533' $35.8^{\prime \prime} \mathrm{N}, 83^{\circ} 44^{\prime} 48.7^{\prime \prime} \mathrm{E}, 225 \mathrm{~m}$ a.s.l, open manmade grounds, under squash, 20.VIII.2007, leg. P.S. Nefediev.

REMARKS. This sample belongs to Symphylella Silvestri, 1902, but it cannot be determined closer to species in larval stage L9.

\section{Family SCUTIGERELLIDAE}

\section{Scutigerella causeyae Michelbacher, 1942}

MATERIAL EXAMINED. $2 \sigma^{7} \sigma^{7}, 1$ (ASU), Russia, southwestern Siberia, Tomsk Area, Tomsk City, Siberian Botanical Garden, hothouse, 21.IV.2000; 1 + (ASU), same locality, 19.XII.2000; $1 \mathrm{O}^{7}$ (ASU), same Area, Tomsk City, University Grove, Betula, 23.IV.2002; 1 +, 1 ad., 3 juv. (ASU), 1 ad. (SMNG), same Area, Tomsk City, University Grove, near Siberian Botanical Garden gate, Padus avium, 19.V.2008, all leg. P.S. Nefediev.

DISTRIBUTION. This is one of the most widespread Scutigerella species in Europe, dwelling in near-natural and anthropogenic habitats in many European countries ranging from Sweden together with Gotland Island in the north through Belgium, Germany, Austria, Slovenia, Croatia, Bosnia and Herzegovina and Ukraine to mainland Italy and Spain including Alboran Island in the south; it also inhabits Great Britain together with the Shetlands, the Orkneys, the Hebrides and the Isle of Man [Lock, 2009; Enghoff, Scheller, 2013].

REMARKS. The above records from a hothouse of the Siberian Botanical Garden in the city of Tomsk, Tomsk Area and from open grounds in the nearby University Grove are new to the fauna of Russia.

\section{Hanseniella sp.}

MATERIAL EXAMINED. $1 O^{\top}$ (ASU), Russia, southwestern Siberia, Tomsk Area, Tomsk City, Siberian Botanical Garden, hothouse, 19.XII.2000, leg. P.S. Nefediev.

DISTRIBUTION. The genus Hanseniella Bagnall, 1913, comprises 82 species worldwide [Szucsich, Scheller, 2011]. Only one species, Hanseniella nivea (Scopoli, 1763), has hitherto been known to occur in Russia, namely, in the Caucasus [Lignau, 1903, 1915; Muralewicz, 1910, 1913] and the Crimea [Lignau, 1905]. Because the examined specimen was found in a hothouse of the Siberian Botanical Garden, it may have come from anywhere in the world.

REMARKS. The genus Hanseniella is new to the fauna of the Asian part of Russia.

\section{Conclusions}

To date, at least three species of Symphyla are known to occur in Siberia, Asian Russia: Symphylella 
cf. vulgaris (Hansen, 1903), Scutigerella causeyae Michelbacher, 1942, and Hanseniella sp. All present findings of symphylans being confined to a botanical garden, city park and open man-made grounds strongly suggest that they are non-native to Siberia. Two species, i.e. $S$. cf. vulgaris and $S$. causeyae, are adapted to life not only in hothouses but also outdoors, yet their distribution in Siberia known so far is strictly associated with areas of human activity.

More species may thus be expected to occur in greenhouses or other anthropogenic habitats such as, e.g., Hanseniella oligomacrochaeta Scheller, 2002, Symphylella vulgaris (Hansen, 1903), Hanseniella caldaria (Hansen, 1903), Hanseniella orientalis (Hansen, 1903), or Hanseniella unguiculata (Hansen, 1903) [Edwards, 1959; Hopkin, Roberts, 1988; Scheller, 2008].

ACKNOWLEDGEMENTS. We thank E.V. Mikhaljova (Vladivostok, Russia) for providing additional literature. The English was kindly checked by S.I. Golovatch (Moscow, Russia).

\section{References}

Andersson G., Meidell B.A., Scheller U., Winqvist, J.-Å., Osterkamp Madsen M., Djursvoll P., Budd G., Gärdenfors U. 2005 Nationalnyckeln till Sveriges flora och fauna. Mångfotingar. Myriapoda. Uppsala: ArtDatabanken, SLU. 351 p.

Domínguez Camacho M. 2009. Phylogeny of the Symphyla. PhD Thesis. Freie Universität Berlin. 147 p.

Edwards C.A. 1959. A revision of the British Symphyla // Proceedings of the Zoological Society of London. No.132. P.403-439.

Enghoff H., Scheller U. 2013. Fauna Europaea: Symphyla // Fauna Europaea, version 2.6.2. Available online at http:// www.faunaeur.org (accessed 23 November 2015).

Farzalieva G.Sh. 2008. [The fauna and chorology of Myriapoda from the Urals and Cisuralia]. PhD Thesis. Perm State University. 189 p. [in Russian].

Hansen H.J. 1903. The genera and species of the order Symphyla // Quarterly Journal of Microscopical Science. N.S. Vol.47. P.1-101 [with plates 1-7]

Hopkin S.P., Roberts A.W. 1988. Symphyla - the least studied of the most interesting soil animals // Bulletin of the British Myriapod Group. No.5. P.28-34.
Lignau N.G. 1903. [Myriapods of the Black Sea coast of the Caucasus] // Zapiski Novorossijskogo obshchestva estestvoispytatelei. Vol.25. No.1. P.82-148 [in Russian].

Lignau N.G. 1905. [Myriapods of the Crimea] // Zapiski Novorossijskogo obshchestva estestvoispytatelei. Vol.28. P.197199 [in Russian].

Lignau N.G. 1915 (for 1914). Vielfüssler aus Abchasien // Ezhegodnik Zoologicheskogo muzeya imperatorskoi akademii nauk. No.19. P.349-401.

Lock K. 2010. Symphyla of Belgium // Entomologie faunistique Faunistic Entomology. Vol.62. No.1. P.25-27 [for 2009].

Michelbacher A.E. 1942. A synopsis of the genus Scutigerella (Symphyla: Scutigerellidae) // Annals of the Entomological Society of America.Vol.35. No.3. P.267-288.

Muralewicz V.S. 1910. [An essay on the Myriapoda fauna of the Crimea] // Zapiski Kavkazskogo muzeya. No.5. P.1-80 [in Russian].

Muralewicz V.S. 1913. [The fauna of the Black Sea coast. Myriapods] // Trudy Obshchestva izucheniya Chernomorskogo poberezhiya. No.2. P.215-221 [in Russian].

Scheller U. 1978. The Pauropoda and Symphyla of the Geneva Museum V. A review of the Swiss Scolopendrellidae (Myriapoda, Symphyla) // Revue suisse de Zoologie. T.85. Fasc.2. P.247-263.

Scheller U. 2008. A new species of Hanseniella Bagnall (Myriapoda, Symphyla) found in a hothouse // Zoosystematics and Evolution. Vol.78. No.2. P.269-273.

Scheller U., Adis J. 1996. A pictorial key for the symphylan families and genera of the Neotropical region south of central Mexico (Myriapoda, Symphyla) // Studies on Neotropical Fauna and Environment. No.31. P.57-61.

Scheller U., Golovatch S.I. 1982. [Centipedes of the class Symphyla in the USSR] // Zoologicheskii Zhurnal. Vol.61. No.1. P.143145 [in Russian, with English summary].

Scheller U., Mikhaljova E.V. 2001 (for 2000). New records of Symphyla (Myriapoda) from the Russian Far East // Arthropoda Selecta. Vol.9. No.1. P.29-30.

Scheller U., Stoev P. 2006. First records of Symphyla (Myriapoda) from Bulgaria // Historia naturalis bulgarica. No.17. P.35-37.

Szucsich N., Scheller U. 2011. Symphyla // A. Minelli (ed.). Treatise on zoology - anatomy, taxonomy, biology. The Myriapoda. Volume 1. Brill: Leiden-Boston. P.445-466.

Voigtländer K., Decker P., Burkhardt U., Spelda J. 2016. The present knowledge of the Symphyla and Pauropoda (Myriapoda) in Germany - An annotated checklist // Acta Societatis Zoologicae Bohemicae. Vol.80. No.1.

Responsible editor S.I. Golovatch 